\title{
Life Writing in the Era of Genetics: Contemporary Genetic Risk Narratives in Great Britain and America
}

\author{
Tingting Zhou ${ }^{1}$ \\ ${ }^{1}$ School of Foreign Languages, Southwest University of Political Science and Law, Chongqing, 401120, China \\ Correspondence: Tingting Zhou, School of Foreign Languages, Southwest University of Political Science and \\ Law, Chongqing, 401120, China. E-mail: 945266546@qq.com
}

Received: June 20, 2021

Accepted: July 25, $2021 \quad$ Online Published: July 29, 2021

doi:10.5539/ells.v11n3p45

URL: https://doi.org/10.5539/ells.v11n3p45

\begin{abstract}
The development of genetic science brings forth a third group besides the healthy and the ill: the high-risk group who carries certain disease-related genes. In the era of genetics, people try to assess risks with statistical numbers and eliminate risks by Western medical measures. In this context, personal genetic risk narratives (usually in the form of memoirs) emerged in Great Britain and America in the 1990s. The thesis has a close reading of three British and American genetic risk memoirs and wants to find the characteristics and values of the new genre. The memoirs are featured by their vivid description of the narrator's difficult and complex situation in face of genetic risks. In an era when the body is dominated by statistical numbers, these narratives make personal meaning of impersonal statistics. Genetic risk narratives express a strong belief in genetic technology and Western medical myth. However, the narrative divergence and self-contradiction in the memoirs exposes the limitation of genetic determinism and thus deconstructs the Western medical myth.
\end{abstract}

Keywords: genetic risk narratives, risk, statistics

\section{Introduction}

On May $14^{\text {th }}$, 2013, American star Angelina Julie published My Medical Choice on New York Times. In this report, she told her experiences of having a preventive mastectomy after testing positive of BRCA1 gene mutation. Julie's mother and grandmother both died of breast cancer. A DNA test showed Julie had inherited the mutation from her mother. To avoid the tragedy of her mother and grandmother, Julie chose to have a preventive mastectomy to reduce her chance of developing breast cancer from $87 \%$ to $5 \%$. After the mastectomy, she believed she had conquered the risk of breast cancer.

Julie's story is a typical genetic risk narrative. In recent years, with the development of genetic science, more and more genes of inheritable diseases have been located. Genetic DNA tests enable people to know whether they carry disease-related genes and make it possible to detect the risk before they get ill. In this context, in the 1990s, genetic risk narratives began to emerge in Great Britain and America. A genetic risk narrative is an autobiographical narrative of high-risk groups' experiences of their genetic risks.

As a new genre of life writing, the genetic risk narratives record people's new life experiences in the era of genetics. The thesis has a close reading of three representative British and American genetic risk memoirs in order to find the characteristics and values of the genre.

\section{Eradicating Risk by Western Medical Measures}

In the genomic age, the emergence of the technique of DNA testing makes a third group besides the healthy and the ill: the high-risk group with certain disease-related genes. People of high-risk group are healthy now, but they have a higher chance of developing certain diseases in the future. Different from traditional illness narratives, genetic risk narratives do not focus on the diagnosis and treatment of illnesses but on the assessment and control of risks.

Like Julie, Jessica Queller was tested positive for BRCA1 gene mutation. In her memoir Pretty is What Changes: Impossible Choices, the Breast Cancer Gene, and How I Defied My Destiny, Queller described in details her experiences from knowing the test result to her decision of having a preventive mastectomy. Confident of her negative result, Jessica had the test. When she almost forgot the test, she got an unexpected positive result. Jessica regretted taking the test, willing to live in "blissful ignorance" (Queller, 2008, p. 93). Even before 
considering whether she needed the result, she had to face the risk. Since risks are measured by statistics, risk narratives are filled with statistical numbers. Statistics showed Queller's chance of getting breast cancer is $87 \%$ and ovarian cancer is $44 \%$. She also had a $50 \%$ chance of getting breast cancer before age 50 (Queller, 2008, p. 90).

Statistics as a new science appeared in the early $19^{\text {th }}$ century. According to Ian Hacking, the foundation of Western metaphysics is the law of determinism. (1) In the $19^{\text {th }}$ century, people came to realize that the world was not deterministic: the past did not determine what happened next. The decay of determinism paved the way for the law of chance (Hacking, 1990). In the Napoleonic era, chance, in the form of statistical numbers, was used to count many kinds of human behavior such as crime and suicide. Chance made the world seem "less capricious" for it "brought order out of chaos" (Hacking, 1990). During the $20^{\text {th }}$ century, when Western medicine becomes the dominant force in the society, chance is manifest in the statistical calculation of risk of health.

In the United States, to women who have married and have children, doctors' suggestion is to have a preventive mastectomy. However, this suggestion does not suit Queller. She was only 35 and hadn't got a partner yet. The mastectomy would have a negative effect on her later intimate relationship and deprive her of breast feeding. To Queller's disappointment, doctors were unable to offer any alternative suggestion as regard to her situation.

As a matter of fact, the more people feel uncertain about the future, the more people depend on statistics. Statistics, which was first created to describe human behaviors, "came to be regarded as laws in their own right, and their sway was extended to natural phenomena" (Hacking, 1990). In this case, statistical laws become a kind of "objective knowledge" and are used "not only for description but also for explaining and understanding the course of events" (Hacking, 1990). Uncertain about her future, Queller completely depended on statistics to understand her situation. The whole memoir was built around several numbers such as chance of getting breast cancer in a whole life time, chance of getting breast cancer before 50 and chance of getting breast cancer after a preventive mastectomy. Statistical numbers become the driving force of the development of the plot. When Queller knew that a preventive mastectomy could reduce the chance of getting breast cancer from $90 \%$ to $10 \%$, she at last made the decision to have a mastectomy. This dependence became paranoid when she insisted to choose an experienced surgeon to cut as much breast tissue as possible to reduce the chance to $5 \%$.

Queller's narrative had a seemingly happy ending. She had a preventive mastectomy but kept her ovaries. She would purchase sperm and be artificially inseminated. She even planned to use PGD (Preimplantation Genetic Diagnosis) technique to implant a healthy embryo without the faulty gene, though she committed it involved "ethical dilemmas" (Queller, 2008, p. 239).

Queller was a strong believer in biotechnology and Western medicine. She believed after the mastectomy she could escape from the risk. Although Queller's memoir is a triumph story which represents the dominant ideology of American society, it still has its own value. Featured by its vivid description of her complex and difficult situation in face of the genetic risk, it reminds us of the gap between impersonal statistical numbers and personal experiences.

\section{Unexpected Risk: the Dilemma in Genomic Age}

Jessica's narrative comes to an end when she has done the preventive mastectomy, but the end of the narrative does not mean the end of risk. German sociologist Ulrich Beck points out, the modern society is a risk society. Risk is "a systematic way of dealing with hazards and insecurities induced and introduced by modernization itself" (Beck, 1986, p. 21). In the pre-modern society, the hazards could be traced back to "an undersupply of hygienic technology" (Beck, 1986, p. 21). However, in the late-modern society, the dominant threat became human-generated risks like "ecological and high-tech risks" (Beck, 1986, p. 22). In Beck's theory, risk is an unpredictable and uncontrollable force which dominates in the modern society.

Genetic risks belong to those unpredictable and uncontrollable high-tech risks. To an individual, statistics cannot predict risk accurately. Statistics describes possibilities instead of facts. People with BRCA gene mutation have a higher chance of breast cancer but they may not have breast cancer in their life. People with the mutation tend to focus all attention on the risk of breast cancer and forget other risks.

In her memoir Singing the Life: The Story of a Family in the Shadow of Cancer, Elizabeth Bryan, an English pediatrician, described her diagnosis of pancreas cancer after having a preventive mastectomy. The memoir intends to tell the Bryan family's story of cancer history as well as Elizabeth's personal story with BRCA1 gene mutation. The Brian family had many cancers in the past generations. Trained in medicine, Bryan was quite risk-conscious. Before she got the positive result of BRCA1 gene mutation (the test didn't appear until the 1990s), she had examination of breasts and ovaries every year to detect early symptoms. In the 1990s, after her 
sisters' diagnosis of breast cancer and ovarian cancer one after another, she had her breasts and ovaries removed to eliminate the risk once and for all. When she felt certain that the risk had gone away already, she was diagnosed with pancreas cancer.

The 5-year survival rate of pancreas cancer is $2-3 \%$, much lower than breast cancer and ovarian cancer. Because the threat was fatal, Bryan had to change her topic and divert her attention to tell her combat with pancreas cancer. It was quite prominent that in a memoir about BRCA1 gene mutation the gene had become absent in about one hundred pages. Although at the end of the memoir, Bryan returned to the topic of BRCA gene mutation and tried to prove the necessity of genetic test, the narrative divergence exposed the limitation of gene determinism.

Singing the Life is an ironic risk narrative. The expected risk does not become a reality; what really comes true is the risk the author never thinks of. The reader expects a triumph story of changing one's fate with the help of biotechnology and Western medicine, but what they read in fact is a story of pancreas cancer. Bryan's memoir exposes the dilemma in genomic age: people try their best to control risks, only to find risks cannot be eradicated once and for all.

\section{Local People's Wisdom: Living with Risk}

The emergence of statistics is to control risk but the dilemma is that we are controlled by a statistical panic. According to Kathleen Woodward, statistical panic is the situation that "fatally we feel that a certain statistic, which is in fact based on an aggregate and is only a measure of probability, represents our very future — or the future of someone we love" (Woodward, 2009, p. 196). This statistic panic is most vividly manifest in American historian Alice Wexler's memoir about Huntington's disease.

Mapping Fate: A Memoir of Family, Risk, and Genetic Research is Alice Wexler's personal memoir of Huntington's as well as a scientific memoir about the scientific process of locating the gene. Huntington's disease causes progressive degeneration of nerve cells in the brain, which affects voluntary and involuntary movement, impairs cognition, and can cause psychiatric disorders. Wexler's mother died of the disease. As a historian, Wexler recorded the scientific process of locating the gene and made a documentary.

As Huntington's is a heritable disease that is carried on a single gene, Wexler had a $50 \%$ chance of having inherited the gene from her mother. Although it sounded "not too bad" (Wexler, 1995, p. 43), "50\%" represented an extreme uncertainty. As her sister Nancy wrote, "The ambiguous condition of 50 percent risk is extremely difficult to maintain in one's mind, if not impossible. In practice a 50-50 risk translates to a 100 percent certainty that one will or will not develop the disease" (Wexler, 1995, p. 223).

The statistic panic was even worsened when the genetic marker was discovered in 1983. High-risk group could know whether they carry the gene by a DNA test. Some people could not bear the uncertainty and chose to have the test. Wexler had to make the decision whether she would have the test.

Contemporary westerners have a stubborn persistence to risk control. Modern Western medicine tries to draw a clear line between illness and health and does not tolerate the ambiguity of being at risk. As Queller commented in her memoir, "as soon as someone tests positive for a BRCA mutation, she is treated like a cancer patient" (Queller, 2008, p. 92). To eradicate the risk, women are asked to have a mastectomy even if there is no symptom of breast cancer at all. The radical medical measures mean to control risk but ignore the trauma women may suffer from after a mastectomy.

As regard to Huntington's disease, the situation was a little different. When Wexler wrote the memoir, the DNA test could only test whether people carry the gene but could not offer any treatment. To those people who wanted to get rid of uncertainty, they had to face the fact that if tested positive, there was no treatment to cure or change the course of the disease.

In face of the dilemma, Wexler decided not to have the gene test. She chose to live with the risk. Wexler's epiphany came from a Venezuelan community's wisdom of living with risk. Racked with Huntington's, this small community in Venezuela had a different way to understand the risk. They believed that everyone who had a parent with the disease always inherited it from that parent, but only some people actually developed the symptoms (Wexler, 1995, p. 196). In this way, they acknowledged the risk and didn't worry whether they would have the illness or not and when they would develop symptoms. Wexler realized that besides being healthy and being ill, being at risk was a state all its own. She rejected the "sharp categories of binary definitions" of health and illness and even enjoyed the "ambiguity" of being at risk (Wexler, 1995, p. 238). Inspired by the wisdom of people from a different culture, Wexler found her inner peace.

The memoir of Wexler is both a scientific memoir and a personal narrative. But there's a contradiction between 
the scientific discourse about Huntington's and her personal experience. In recording the scientific progress in locating the gene of Huntington's disease, Wexler showed confidence in the power of Western genetic science to overcome the disease. However, when talking about her own story, she revealed a statistic panic in living with a "50\%" chance. Ironically, Wexler's redemption was achieved by local people's philosophy of risk instead of by Western medicine.

\section{Conclusion}

In the modern society, human body has become a statistical body. The prevalence of statistical numbers leads to the lack of personal narratives and underscores the value of genetic risk memoirs. Describing unique and new life experiences of individuals in genomic age, genetic risk memoirs reveal the fact that "while general population can be described with probabilities, the life of an individual cannot" (Jurecic, 2012, p. 21). Although genetic risk narratives believe in genetic determinism and Western medicine, the narrative divergence and contradiction exposes the limitation of genetic determinism and deconstructs the Western medical myth.

\section{Acknowledgments}

The thesis is sponsored by the research program "A Study on Contemporary American Autopathography" of Chongqing Municipal Educational Committee (20SKGH003) and Southwest University of Political Science and Law (2019XZYB-07).

\section{References}

Beck, U. (1986). Trans. Mark Ritter. Risk Society: Towards a New Modernity. London: Sage Publication. Bryan, E. (2007). Singing the Life: The Story of a Family in the Shadow of Cancer. London: Vermilion.

Hacking, I. (1990). The Taming of Chance. Cambridge: Cambridge University Press. https://doi.org/10.1017/CBO9780511819766

Julie, A. (2013). My Medical Choice. New York Times. May 14.

Jurecic, A. (2012). Illness as Narrative. Pittsburgh: University of Pittsburgh Press. https://doi.org/10.2307/j.ctt5hjr8p

Queller, J. (2008). Pretty is What Changes: Impossible Choices, the Breast Cancer Gene, and How I Defied My Destiny. New York: Spiegel \& Grau.

Wexler, A. (1995) Mapping Fate: A Memoir of Family, Risk and Genetic Research. Berkeley: University of California Press.

Woodward, K. (2009). Statistic Panic: Cultural Politics and Poetics of the Emotions. Durham: Duke University Press. https://doi.org/10.1215/9780822392316

\section{Copyrights}

Copyright for this article is retained by the author, with first publication rights granted to the journal.

This is an open-access article distributed under the terms and conditions of the Creative Commons Attribution license (http://creativecommons.org/licenses/by/4.0/). 